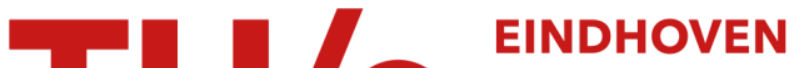 UNIVERSITY OF TECHNOLOGY
}

\section{PHASAR-based PICs for WDM-applications}

Citation for published version (APA):

Smit, M. K. (1997). PHASAR-based PICs for WDM-applications. In 1997 Digest of the LEOS Summer Topical Meetings [ IEEE/LEOS summer topical meetings, 1997, Montreal] (pp. 86-87). Institute of Electrical and Electronics Engineers.

\section{Document status and date:}

Published: 01/01/1997

\section{Document Version:}

Publisher's PDF, also known as Version of Record (includes final page, issue and volume numbers)

\section{Please check the document version of this publication:}

- A submitted manuscript is the version of the article upon submission and before peer-review. There can be important differences between the submitted version and the official published version of record. People interested in the research are advised to contact the author for the final version of the publication, or visit the $\mathrm{DOI}$ to the publisher's website.

- The final author version and the galley proof are versions of the publication after peer review.

- The final published version features the final layout of the paper including the volume, issue and page numbers.

Link to publication

\section{General rights}

Copyright and moral rights for the publications made accessible in the public portal are retained by the authors and/or other copyright owners and it is a condition of accessing publications that users recognise and abide by the legal requirements associated with these rights.

- Users may download and print one copy of any publication from the public portal for the purpose of private study or research.

- You may not further distribute the material or use it for any profit-making activity or commercial gain

- You may freely distribute the URL identifying the publication in the public portal.

If the publication is distributed under the terms of Article $25 \mathrm{fa}$ of the Dutch Copyright Act, indicated by the "Taverne" license above, please follow below link for the End User Agreement:

www.tue.nl/taverne

\section{Take down policy}

If you believe that this document breaches copyright please contact us at:

openaccess@tue.nl

providing details and we will investigate your claim. 


\title{
PHASAR-based PICs for WDM-applications
}

\author{
M.K. Smit \\ Delft University of Technology \\ Department of Electrical Engineering, P.O. Box 5031, 2600 GA Delft, \\ The Netherlands \\ Tel: + 31-15-2782279, Fax: +31-15-2784046, E-mail: smit@et.tudelft.nl
}

\begin{abstract}
Wavelength multiplexers, demultiplexers and routers based on optical phased arrays play a key role in multi-wavelength telecommunication links and networks. Photonic integration of PHASARS with active components will provide the functionality required in tomorrows multi-wavelength networks.
\end{abstract}

\section{SUMMMARY}

Commercial interest in multi-wavelength components and systems is rapidly increasing. WDM provides a new dimension for solving capacity and flexibility problems in the telecommunication network. It offers a huge transmission capacity and allows for novel network architectures which offer much more flexibility than the current networks [1,2]. Multiwavelength links and networks require optical components with an increased functionality, such as multi wavelength (MW) receivers, MW-sources, add-drop multiplexers and optical cross connects.

A key component in MW-devices and circuits is the wavelength (de)multiplexer. Phased array (PHASAR) demultiplexers have proven to be robust components [3] which are particularly suitable for integration with other components. Integration with detectors in MW-receivers [4,5], with optical amplifiers in MW-lasers [6,7] and with optical switches in MW-add-drop multiplexers $[8,9]$ has been reported.

Photonic integration offers the potential to provide the functionality required in future MWnetworks in a compact way. Performance and fabrication issues of integrated PHASAR-based devices will be discussed. 


\section{References.}

[1] C.A. Brackett, "Dense wavelength division multiplexing networks: principles and applications", IEEE J. Select. Areas Comm., Vol. 8, pp. 948-964, 1990.

[2] C.A. Brackett, A.S. Acampora, J. Sweitzer, G. Tangonan, M.T. Smith, W. Lennon, K.C. Wang, R.H. Hobbs, "A scalable multiwavelength multihop optical network: A proposal for research on all-optical networks", J. Lightw. Technol., 11 (5/6), pp. 736-753, May/June 1993.

[3] M.K. Smit, PHASAR-based WDM devices: principles, design and applications, invited paper, J. of Sel. Topics in Quantum. Electron., Vol. 2, No. 2, pp. 236-250, June 1996.

[4] M. Zirngibl, C.H. Joyner and L.W. Stulz, "WDM receiver by monolithic integration of an optical preamplifier, waveguide grating router and photodiode array", El. Lett., 31 (7), pp. 581-582, March 1995.

[5] C.A.M. Steenbergen, C. van Dam, A. Looijen, C.G.P. Herben, M. de Kok, M.K. Smit, J.W. Pedersen, I. Moerman, R.G. Baets and B.H. Verbeek, "Compact lowloss $8 \times 10 \mathrm{GHz}$ Polarisation independent WDM Receiver", Proc. 22nd Eur. Conf. on Opt. Comm. ECOC 96, Oslo, Sept. 15-19, 1996, Vol.1, pp. 129-132.

[6] M. Zirngibl, C.H. Joyner, C.R. Doerr, L.W. Stulz, H.M. Presby, "A 18 channel multi frequency laser", Integrated Photonics Research 1996, Boston, USA, April 29 - May 2, pp. 128-131, 1996.

[7] A.A.M Staring, L.H. Spiekman, J.J.M. Binsma, E.J. Jansen, T. van Dongen, P.J.A. Thijs, M.K. Smit, and B.H. Verbeek, "A compact 9 channel multiwavelength laser", IEEE Photon. Technol. Lett., Vol. 8, nr. 9, pp. 11391141, Sept. 1996.

[8] K. Okamoto, K. Takiguchi and Y. Ohmori, "16-channel add/drop multiplexer using silica-based arrayed-waveguide gratings", El. Lett., 31 (9), pp. 723-724, April 1995.

[9] C.G.M. Vreeburg, T. Uitterdijk, Y.S. Oei, M.K. Smit, F.H. Groen, E.G. Metaal, P. Demeester and H.J. Frankena, "First InP-based reconfigurable integrated add-drop multiplexer", Photonic Technol. Lett., Vol. 9, No. 2, pp. 188-190, Feb. 1997 